\title{
Erratum
}

\section{Impact of medical specialists' locus of control on communication skills in oncological interviews}

\author{
Y Libert ${ }^{1,2}$, P Janne', D Razavi' ${ }^{2}$ I Merckaert ${ }^{2}$, P Scalliet', N Delvaux ${ }^{2}$, A-M Etienne ${ }^{3}$, S Conradt ${ }^{3}$, J Klastersky ${ }^{2}$, \\ J Boniver ${ }^{3}$ and Ch Reynaert' \\ 'Universite Catholique de Louvain, Belgium; ${ }^{2}$ Universite Libre de Bruxelles, Belgium; ${ }^{3}$ Universite de Liege, Belgium
}

British Journal of Cancer (2003) 88, 2004-2005. doi:I0.1038/sj.bjc.6600966 www.bjcancer.com

(c) 2003 Cancer Research UK

Correction to: British Journal of Cancer (2003) 88, 502 - 509. doi: 10.1038/sj.bjc.6600797

Unfortunately because of a typesetting error, Tables 1 and 3 were reproduced incorrectly. The correct versions are printed below:

Table I Socioprofessional characteristics of physicians with internal and external LOC (upper and lower quartiles of the Rotter I-E scale scores distribution)

\begin{tabular}{|c|c|c|c|c|}
\hline \multirow{2}{*}{ Age (years) } & \multicolumn{2}{|c|}{ Internal LOC } & \multicolumn{2}{|c|}{ External LOC } \\
\hline & & & & \\
\hline Mean (s.d.) & 43 & $(6.3)$ & 39 & (5.7) \\
\hline \multicolumn{5}{|l|}{ Gender } \\
\hline Male & 16 & (72.7) & 8 & (44.4) \\
\hline Female & 6 & $(27.3)$ & 10 & $(55.6)$ \\
\hline \multicolumn{5}{|l|}{ Medical speciality } \\
\hline Oncology & 5 & $(22.7)$ & 7 & (38.9) \\
\hline Radiotherapy & 3 & $(13.6)$ & 2 & $(11.1)$ \\
\hline Haematology & - & - & 4 & $(22.2)$ \\
\hline Gynaecology & 4 & $(18.2)$ & 3 & $(16.7)$ \\
\hline Others & 10 & $(45.5)$ & 2 & $(11.1)$ \\
\hline \multicolumn{5}{|l|}{ Medical specialisation training achieved } \\
\hline Yes & 20 & $(90.9)$ & 18 & $(100)$ \\
\hline No & 2 & $(9.1)$ & - & - \\
\hline \multicolumn{5}{|l|}{ Medical practice (years) } \\
\hline Mean (s.d.) & 17 & $(6.5)$ & 14 & $(5.5)$ \\
\hline \multicolumn{5}{|l|}{ Medical practice in oncology (years) } \\
\hline Mean (s.d.) & 13 & $(6.8)$ & 11 & (6.4) \\
\hline \multicolumn{5}{|l|}{ Number of cancer patients cared during last week } \\
\hline Mean (s.d.) & 19 & $(17.3)$ & 26 & $(18.0)$ \\
\hline \multicolumn{5}{|l|}{ Medical practice } \\
\hline In hospital & 18 & $(81.8)$ & 15 & (83.3) \\
\hline In one-day clinic & 10 & $(45.5)$ & 8 & $(44.4)$ \\
\hline Private & 6 & $(27.3)$ & 5 & $(27.8)$ \\
\hline \multicolumn{5}{|l|}{ Previous training in communication skills in the last year } \\
\hline Workshops, readings, conferences and others & 10 & $(45.5)$ & 9 & $(50.0)$ \\
\hline
\end{tabular}

Except when stated otherwise, values are expressed as frequencies, percentages are between brackets. No statistically significant differences were found between both groups except for the fact that all the haematologists were in the group of physicians with external LOC and the two physicians still in medical specialisation training were in the group of physicians with internal LOC. 
Table 3 Characteristics of interviews led by physicians with internal and external LOC (upper and lower quartiles of the Rotter I-E scale scores distribution)

\begin{tabular}{|c|c|c|c|c|}
\hline Age (years) & \multicolumn{2}{|c|}{ Internal LOC } & \multicolumn{2}{|c|}{ External LOC } \\
\hline \multicolumn{5}{|l|}{ Gender } \\
\hline \multicolumn{5}{|l|}{ School level completed ${ }^{\mathrm{a}}$} \\
\hline Junior high school or less & 6 & $(30.0)$ & 3 & $(17.7)$ \\
\hline \multicolumn{5}{|l|}{ Karnofsky performance status $(K P S)^{a}$} \\
\hline 80 or more & 14 & $(70.0)$ & 14 & (82.4) \\
\hline Less than 80 & 6 & (30.0) & 3 & $(17.7)$ \\
\hline \multicolumn{5}{|l|}{ Hospital anxiety and depression scale (HADS) } \\
\hline Emotional distress total mean scores (s.d.) & 11.0 & (5.3) & 11.8 & (6.2) \\
\hline \multicolumn{5}{|l|}{ Multidimensional health locus of control (MHLC) } \\
\hline Internal HLC mean scores (s.d.) & 24.6 & $(5.2)$ & 22.7 & (5.5) \\
\hline \multicolumn{5}{|l|}{ Prognosis } \\
\hline Less than I year & 7 & $(35.0)$ & 4 & $(23.5)$ \\
\hline I year or more & 13 & $(65.0)$ & 13 & $(76.5)$ \\
\hline \multicolumn{5}{|l|}{ Disease status } \\
\hline In remission, no change or too early to assess & 13 & (35.0) & 12 & $(70.6)$ \\
\hline In progression & 7 & $(65.0)$ & 5 & $(29.4)$ \\
\hline \multicolumn{5}{|l|}{ Current cancer treatment } \\
\hline Yes & 9 & $(45.0)$ & 11 & $(64.7)$ \\
\hline No & II & $(55.0)$ & 6 & $(35.3)$ \\
\hline \multicolumn{5}{|l|}{ Months since diagnosis } \\
\hline Mean (s.d.) & 29 & $(43.1)$ & 37 & $(54.7)$ \\
\hline \multicolumn{5}{|l|}{ Type of information } \\
\hline Diagnosis related & 11 & (55.0) & 5 & (29.4) \\
\hline Not diagnosis related & 9 & $(45.0)$ & 12 & $(70.6)$ \\
\hline
\end{tabular}

Except when stated otherwise, values are expressed as frequencies, percentages are in brackets. No statistically significant differences were found between both groups. ${ }^{a} \chi^{2}$ not applicable because of a lack of observations in the cells.

The publisher would like to apologise for any inconvenience this may have caused. 